\title{
Climate Finance: Too Much on Detail, Too Little on the Big Picture?
}

\author{
Ralph Bodle and Vicky Noens*
}

At the climate conference in Katowice, Poland, in December 2018 (COP 24), Parties to the Paris Agreement intend to adopt a comprehensive set of decisions that provide details on its implementation, based on the so-called Paris Agreement Work Programme (PAWP). We outline some of the many finance issues to be addressed COP 24 and look more in-depth at two particular issues: the overarching goal regarding finance flows in Article 2(1)(c); and transparency of support. Article 2(1)(c) is a major innovation because it establishes addressing financial flows as one of the three goals of the Paris Agreement. At the same time it is an essential means to achieve the mitigation and adaptation goals. Article 2(1)(c) has a transformational objective with huge potential implications in the real world. Despite its overarching importance, the current negotiations do not address Article 2(1)(c) in the holistic manner it requires. Transparency of support relates to the delivery of information and data on financial and other support within the UNFCCC. The Paris Agreement requires Parties to 'build on and enhance' the existing transparency arrangements. The current negotiations are focused mainly on the financial support provided by developed countries, with less time dedicated towards support received and other parts of the bigger picture. If it was more balanced and addressed all aspects of transparency of support, the real-world impact of the transparency framework could be considerable.

\section{Introduction}

Climate finance has always been an important issue in the climate regime as an enabler for climate action and way to increase the level of ambition for mitigation and adaptation. ${ }^{1}$

Similar to other topics, climate finance has evolved from when the United Nations Framework Convention on Climate Change (UNFCCC) was adopted in 1992 to the Paris Agreement in 2015. The general obligations in the UNFCCC on developed countries

DOI: $10.21552 / \mathrm{cclr} / 2018 / 3 / 11$

* Ralph Bodle, Senior Fellow, Ecologic Institute; Vicky Noens, Policy Advisor, Division Strategy, International Policy and Animal Welfare, Department of Environment and Spatial Development, Government of Flanders. For correspondence: $<$ ralph .bodle@ecologic.eu>; <vicky.noens@vlaanderen.be>. Responsibility for the contents of this article lies with the authors.

1 Without prejudice to the discussion on definitions and terminology, we use the term 'climate finance' in a broad sense, including public, private and other finance. The UNFCCC website states that ' $[c]$ limate finance refers to local, national or transnational financing - drawn from public, private and alternative sources of to provide financial and other support to developing countries were specified, for instance regarding scale, sources, balance, prioritization, reporting and institutions. ${ }^{2}$ Finance also played an important part in negotiating the Paris Agreement in terms of building on the UNFCCC and capturing this evolution, but also in terms of fitting finance into the Paris architecture and providing new impulses for the future regime. The so-called Paris Agreement Work Programme (PAWP) outlined in Decision 1/CP.21 therefore contains numerous mandates regarding finance. financing - that seeks to support mitigation and adaptation actions that will address climate change', see $<$ https://unfccc.int/ topics/climate-finance/the-big-picture/introduction-to-climate -finance> accessed 20 September 2018.

2 For details on the negotiating history see Jorge Gastelumendi and Inka Gnittke, 'Climate Finance (Article 9)' in Daniel Klein and others (eds), The Paris Agreement on Climate Change: Analysis and Commentary (Oxford University Press, 2017 239, 240-242. See also the overviews on: <https://unfccc.int/topics/climate -finance/the-big-picture/introduction-to-climate-finance $>$; $<$ https://unfccc.int/topics/climate-finance/the-big-picture/climate -finance-in-the-negotiations $>$; and $<$ https://unfccc.int/ climatefinance?home $>$ accessed 20 September 2018. 
In this article we first outline some of the main finance issues to be addressed at the 24th Conference of the Parties (COP 24) in Katowice in December 2018, before looking more in-depth at two particular issues: The overarching goal regarding finance flows in Article $2(1)(c)^{3}$ and transparency of support. The former is new and under-discussed, while the latter is long established and over-discussed. The article concludes with a tentative perspective on potential outcomes at COP 24.

\section{Finance Issues for COP 24}

The main finance issues at stake at COP 24 do not all stem directly from the Paris Agreement, ${ }^{4}$ but also from the accompanying 'Paris Decision' (1/CP.21), which also addresses issues that were not included in the legal treaty text, and which contains a work programme for elaborating details and modalities. ${ }^{5}$

While the Paris Agreement does not contain quantified obligations regarding financial support, the Paris Decision extends the existing developed coun-

3 Articles without further specification refer to the Paris Agreement. For ease of reference, in this article 'countries' and 'states' should be read as including the European Union, unless otherwise stated.

4 Paris Agreement (adopted 12 December 2015, entered into force 4 November 2016) 55 ILM 740.

5 UNFCCC 'Decision 1/CP.21, Adoption of the Paris Agreement' UN Doc FCCC/CP/2015/10/Add.1 (29 January 2016). For the legal structure of the Paris outcome see Ralph Bodle and Sebastian Oberthür, 'Legal Form of the Paris Agreement and Nature of Obligations' in Klein and others (n 2) 91, 91-92.

6 Decision 1/CP.21 (n 5) para 53. On the specific legal wording used for the finance provisions see Sebastian Oberthür and Ralph Bodle, 'Legal Form and Nature of the Paris Outcome' (2016) 6 Clim L 40, 54 .

7 See UNFCCC 'Informal notes prepared under their own responsibility by the co-facilitators of agenda items 3-8 of the Ad Hoc Working Group on the Paris Agreement' FCCC/APA/2018/L.2/Add.1 (10 May 2018), 162

8 Paris Agreement (n 4) art 9(5) builds on the periodic submissions on the 'strategies and approaches' for scaling up climate finance which were based on UNFCCC 'Decision 1/CP.18, Agreed Outcome Pursuant to the Bali Action Plan' UN Doc FCCC/CP/2012/8/Add.1 (28 February 2013) para 67; and 'Decision 3/CP.19, Long-term Climate Finance' UN Doc FCCC/CP/2013/10/Add.1 (31 January 2014) para 12.

9 Decision 1/CP.21 (n 5) para 55.

10 See eg Decision 1/CP.21 (n 5) para 58,59, 63.

11 ibid para 59; UNFCCC 'Decision 1/CP.22, Preparations for the Entry Into Force of the Paris Agreement and the First Session of the Conference of the Parties Serving as the Meeting of the Parties to the Paris Agreement' UN Doc FCCC/CP/2016/10/Add.1 (31 January 2017) para 14; UNFCCC 'Decision 1/CMP.13, Report of the Adaptation Fund Board' UN Doc FCCC/KP/CMP/2017/7/Add.1 (8 February 2018) paras 12-14; Ralph Czarnecki and Kaveh Guilanpour, 'The Adaptation Fund after Poznan' (2009) 3 CCLR 79. tries' collective goal of mobilising USD 100 billion per year until 2025 and decides that the Conference of the Parties serving as the Meeting of the Parties to the Paris Agreement (CMA) shall set a new quantified goal 'prior to 2025'. ${ }^{6}$ The decision does not specify any process, who the new goal should apply to, or other particulars. Following demands by developing countries, parties are currently discussing under the agenda item 8 on 'other matters' of the Ad Hoc Working Group on the Paris Agreement (APA) mainly when consideration of setting the new goal should begin, under which body, whether there should be some form of formal process that leads to the CMA setting the goal, and whether these questions should be addressed at COP $24{ }^{7}$

Another hot topic is information on climate finance. Information is provided ex post through the transparency framework, which we discuss in more detail in Section IV. In addition, under Article 9(5) developed country Parties have to biennially provide ex ante information. This new obligation ${ }^{8}$ is related to the predictability of financial support and includes, as available, projected levels of public financial resources to be provided to developing country parties. Working on guidance towards a decision at COP 24 has been highly contentious, because the mandate ${ }^{9}$ stipulates 'a process to identify the information to be provided' and Parties have different views on whether this only includes which information is to be provided or also modalities regarding how it is to be provided.

Institutional issues at COP 24 related to finance mainly concern making existing institutions and mechanisms ${ }^{10}$ function under the Paris Agreement. This is not just legal nitty-gritty, but has political and wider implications. In particular, COP 24 is to decide on how the Adaptation Fund, which is under the Kyoto Protocol, is to serve the Paris Agreement. ${ }^{11}$ The Adaptation Fund has particular features and there are different views regarding to what extent these should be maintained when it serves the Paris Agreement. They include, for instance, the current and future sources of funding, whether the Adaptation Fund should serve the Paris Agreement exclusively or in addition to the Kyoto Protocol, its governance structure with a structural majority of developing countries, and even its operating procedures. More generally, COP 24 should address the procedure for providing guidance to institutions that now serve two agreements, notably the UNFCCC and the Paris 
Agreement. This refers in particular to guidance to the operating entities of the financial mechanism, i.e. the Global Environment Facility (GEF) and the Green Climate Fund. Some of the finance issues at COP 24 will be addressed under regular agenda items rather than the APA.

Political issues related to climate finance that play in the background to COP 24 include, for example, progress towards the USD 100 billion goal; the conclusion of the GEF-7 replenishment round in 2018, and the situation regarding funding decisions by the Green Climate Fund and its approaching first formal replenishment. There are also special mandated events at COP 24 such as the biennial high level ministerial on climate finance.

\section{Article 2(1)(c): New and 'Under- Discussed', Not in PAWP}

\section{Context}

Article 2(1)(c) states that the aim of the Paris Agreement includes 'making finance flows consistent with a pathway towards low greenhouse gas emissions and climate resilient development. ${ }^{12}$ It stands next to mitigation and the temperature goals in Article 2.1(a) and adaptation in Article 2.1(b).

Article 3 defines the whole of Article 2 as the purpose of the Paris Agreement and requires ambitious and progressive efforts of all parties over time towards that purpose, including Article 2(1)(c). Article 3 legally links that purpose with specific obligations in other articles. ${ }^{13}$ For instance, the financial provisions in Article 9 are linked, by Article 3, to the overarching purpose in Article 2(1)(c) to transform finance flows. ${ }^{14}$

\section{Importance}

In the Paris negotiations, there was a broad common understanding that finance is an enabler for action and that the global mitigation and adaptation efforts require major shifts in financial flows and private investments. In this sense Article 2(1)(c) is a major innovation because it includes this role of financial flows generally in the purpose of the Paris Agreement, alongside the long-term goals on mitigation and adaptation. ${ }^{15}$ It is a goal of the Paris Agreement in its own right, while at the same time it is an essential means to achieve the mitigation and adaptation goals.

Article 2(1)(c) recognises that public finance alone will not be sufficient for achieving the Paris Agreement's mitigation and adaptation purposes. It does not only refer to public financial support from individual countries or groupings to other countries or groupings. Its scope includes but goes beyond this narrow concept of climate finance and means of implementation.

Article 2(1)(c) is the only textual hook in the Paris Agreement for addressing the bigger picture of general finance and investment flows with other parties under the Paris Agreement, including addressing public and private investment decisions that counteract the objective of the agreement such as high carbon or fossil fuel investments. Notably it includes addressing the conditions which make finance flows go towards mitigation and adaptation. In this sense Article 2(1)(c) is linked to ambition and in the interest of all Parties, even if not all Parties share exactly the same vision and priorities.

\section{Is It Under-Discussed?}

Despite its importance, Article 2(1)(c) can be regarded as under-discussed in the climate negotiations: The Paris Agreement itself does not address specific issues or actions that could help mobilise or redirect financial flows. Proposals to mention improving the conditions for investments in low-carbon development and climate resilience, or more specifically issues such as fossil fuel subsidies, carbon pricing, mainstreaming, were not included in the final text or only play a marginal role, for example in the Paris Decision. For instance, there is one weakly worded reference to the importance of carbon pricing in the Paris Decision's chapter on non-Party stakeholders. ${ }^{16}$ There is also an indirect link in the invitation to United Nations agencies and financial institutions at all levels

\footnotetext{
12 Paris Agreement (n 4) art 2(1)(c).

13 Bodle and Oberthür (n 5) 96.

14 ibid 96, 100.

15 Ralph Bodle, Lena Donat and Matthias Duwe 'The Paris Agreement: Analysis, Assessment and Outlook' (2016) 10 CCLR 5, 7.

16 ibid 7, 16.
} 
to provide information on how they incorporate climate-proofing and climate resilience measures. ${ }^{17}$

For virtually all of its core obligations, the Paris Agreement and the Paris Decision contain mandates for elaborating details and guidance on implementation. ${ }^{18}$ However, there is no mandate specifically on Article 2(1) (c) and it is not directly addressed in the PAWP. $^{19}$

The global stocktake in Article 14 is the notable exception. Its requirement to periodically assess the collective progress towards achieving the purpose of the Paris Agreement includes Article 2(1)(c), which is part of the purpose by virtue of the explicit reference in Article 3. Based on the previous negotiations and informal notes, in August 2018 the APA co-chairs' published 'tools' that could become the draft decision text for the COP 24 outcome. ${ }^{20}$ The tool regarding the global stocktake ${ }^{21}$ contains some options that would include Article 2(1)(c): A process option for conducting the global stocktake includes establishing three workstreams, each assessing one of the long-term goals of the Paris Agreement as stated in Articles 2(1)(a-c) ${ }^{22}$ for the so-called technical phase of the global stocktake, there are options to conduct a technical assessment of collective progress towards achieving the purpose of the Paris Agreement as stated in Article 2(1)(ac) ${ }^{23}$ sources of input relevant specifically on Article $2(1)(\mathrm{c}){ }^{24}$ The tools were further developed during the negotiating session in Bangkok. ${ }^{25}$

Apart from this, Article 2(1)(c) has so far played no or but a very small role in the PAWP. For instance, the co-chairs' tool on nationally determined contributions (NDCs) includes 'policies to attract finance

17 Decision 1/CP.21 (n 5) para 43

18 Bodle and Oberthür (n 5) 96

19 Gastelumendi and Gnittke (n 2) 249, note the potential of the Paris Decision including enabling environments in the 2016 facilitative dialogue, but it does not seem to have started a constructive debate.

20 See, <https://unfccc.int/documents>.

21 UNFCCC 'Additional tool under item 6 of the agenda. Matters relating to the global stocktake referred to in Article 14 of the Paris Agreement: (a) identification of the sources of input for the global stocktake; and (b) development of the modalities of the global stocktake', APA1.6.Informal.1.Add.4 (2 Augsut 2018). See also Jennifer Huang, 'What Can the Paris Agreement's Global Stocktake Learn from the Sustainable Development Goals?' (2018) 12 CCLR.

22 UNFCCC (n 21) Annex, para 5, sub-options 2.1-2.3.

23 ibid Annex, para 38, option 2.

24 ibid Annex, paras 62(h) and 63(c). flows from other resources and the causality between public interventions and mobilized investments', but only for developed country Parties, whereas other countries are only encouraged to provide such information voluntarily. ${ }^{26}$ In addition, the Standing Committee on Finance has picked up on the Paris Agreement and provides information related to Article 2(1)(c) in its Biennial Assessment. ${ }^{27}$

\section{Challenges and Implications}

To put it in simple terms: There is currently no home under the Paris Agreement for Parties to discuss what they could do to achieve one of its three overarching goals - Article 2(1)(c). One of the main challenges for addressing Article 2(1)(c) in the climate negotiations and the package that is to be adopted at COP 24 is the lack of a formal dedicated mandate. There are not many hooks in the Paris Agreement Work Programme for Article 2(1)(c) and at present there is no dedicated agenda item or other home for addressing it in the climate regime. The global stocktake is the exception, as it has to include progress towards all elements of Article 2, including Article 2(1)(c) ${ }^{28}$ Of course, Parties are free to table and address it in the absence of such a mandate, but it requires a different kind of political effort from following the work programme already agreed.

One of the political challenges in anchoring Article $2(1)(c)$ more specifically in the climate negotiations appears to be that Parties are unsure about what addressing it would mean for them individually and

25 Regarding the global stocktake, see for instance UNFCCC, 'Revised additional tool under item 6 of the agenda Matters relating to the global stocktake referred to in Article 14 of the Paris Agreement: (a) identification of the sources of input for the global stocktake; and (b) development of the modalities of the global stocktake' (6 September 2018) (on file with the authors) paras 5, 62(h), 63(c).

26 UNFCCC 'Additional tool under item 3 of the agenda. Further guidance in relation to the mitigation section of decision 1/CP.21 on: (a) features of nationally determined contributions, as specified in paragraph 26; (b) information to facilitate clarity, transparency and understanding of nationally determined contributions, as specified in paragraph 28; and (c) accounting for Parties' nationally determined contributions, as specified in paragraph 31', APA1.6.Informal.1.Add.1 (6 August 2018) in the section on 'information to facilitate clarity, transparency and understanding' of NDCs, p. 17 line 435.

27 See the overview at $<$ https://unfccc.int/topics/climate-finance/ resources/biennial-assessment-of-climate-finance> accessed 20 September 2018

28 Bodle and Oberthür (n 5) 96. 
generally. Parties could be concerned that it could entail obligations on individual Parties to take specific courses of action. However, while Article 3 requires Parties to make ambitious efforts also towards the goal in Article 2(1)(c), there is no indication of a prescriptive 'one size fits all' approach. The range of possible efforts that Parties could make include a myriad of policies and actions that can contribute to the big picture outlined by Article 2(1)(c). ${ }^{29}$ For instance, the 2018 Forum of the Standing Committee on Finance discussed successes and challenges in reducing financial risks and leveraging public and private investments in developing countries, and the gaps and best practices in policies that enable private investments in mitigation and adaptation projects and programmes..$^{30}$ In addition, Article 2 as a whole is framed in the context of poverty reduction, sustainable development, equity and differentiation expressed as the principle of common but differentiated responsibilities and respective capabilities, in the light of different national circumstances. ${ }^{31}$ This dynamic character of Article 2(1)(c) allows developing countries to address finance flows so as to support sustainable development and their poverty reduction priorities. $^{32}$

There could also be concerns that discussing Article $2(1)(c)$ and finance flows more generally could eventually mean less support to developing countries, or developed countries backtracking on their financial commitments. The challenge is to build trust that efforts regarding Article 2(1)(c) are not about shifting the burden from providers and mobilisers of climate finance to the recipient countries, but in the interest of making climate finance more efficient and impactful. ${ }^{33}$

It should also be noted that many other actors, forums and decision-making processes than those of the UNFCCC need to be involved in working towards the goal in Article 2(1)(c), such as legislators, policy, makers, financial institutions and not least those actors whose investments should be realigned and guided. For Parties, action under Article 2(1)(c) is mainly about setting policies in this regard. For instance, the European Commission has adopted a Sustainable Finance Action Plan and submitted legislative proposals. ${ }^{34}$ Different policies will be suitable for different Parties. One of the challenges is to define the appropriate role for Parties in the climate negotiations in relation to those actors and processes 'outside', and to allow for a useful exchange between the two.
There are several options for the climate regime to provide a 'home' for addressing Article 2(1)(c). A new specific agenda item is an obvious one, but it might be difficult to obtain the required consensus at this stage. The process for the global stocktake is another option, but it remains to be seen whether Parties will establish a work stream dedicated to Article $2(1)(c)$ and what its mandate would be. Since the global stocktake is about assessing collective progress, its remit might not adequately cover individual efforts. The transparency framework could include information related to Article 2(1)(c), which would be useful. But the individual reporting system is not ideal for discussing and developing best practices for parties. The Standing Committee on Finance can provide and organise useful assessments, expert input and exchanges, but its workload is already high, and in any event it cannot provide the political space and potential decision-making by Parties.

This leaves the option of addressing Article 2(1)(c) under existing agenda items and mandates. Potential candidates would be items that have a wider perspective than public finance from developing to developed countries. For instance, the current COP agenda item on 'long-term finance' addresses the USD 100 billion commitment, which includes public, private and other sources of finance and finance provided as well as 'mobilised'. It includes mandated events such as biennial high-level ministerial dialogues on climate finance (with the next one to be held during COP 24) and regular in-session workshops. ${ }^{35}$ In a similar vein, Article 2(1)(c) could be included if Parties were to discuss this bigger picture of climate finance

29 Cf the guiding questions in the co-chairs' tool regarding the global stocktake in UNFCCC (n 21) paras 8-13.

30 See 'SCF Forum' (Session 2) <https://unfccc.int/topics/climate -finance/events-meetings/scf-forum/2018-forum-of-the-standing -committee-on-finance> accessed 20 September 2018.

31 Paris Agreement (n 4) arts 2(1), first sentence, and 2(2).

32 Gastelumendi and Gnittke (n 2) 248.

33 As argued with regard to 'enabling environments' in ibid 249.

34 Commission (EU), 'Action Plan: Financing Sustainable Growth' (Communication) COM(2018) 97 final (8 March 2018). For an overview of legislative proposals see $<$ https://ec.europa.eu/info/ publications/180524-proposal-sustainable-finance $>$ accessed 20 September 2018. See also the European Parliament Resolution of 29 May 2018 on sustainable finance $(2018 / 2007($ INI)).

35 See Decision 3/CP.19 (n 8) and UNFCCC 'Decision 5/CP.20 Longterm Climate Finance' UN Doc FCCC/CP/2014/10/Add.2 (2 February 2015); See also <https://unfccc.int/topics/climate -finance/workstreams/long-term-climate-finance> accessed 20 September 2018. 
under the Paris Agreement in the future. In any event, it would be a missed opportunity if a home for further work on Article 2(1)(c) was not established in some way at COP 24.

\section{Real-World Impacts}

Article 2(1)(c) has a transformational objective with huge potential implications in the real world. It is also essential for bringing mitigation and adaptation goals within reach in the long run.

Legally speaking, the Paris Agreement addresses states, not the private and other actors that also decide and influence where finance flows go. In this sense, the real-world impact of addressing Article $2(1)(c)$ in the climate negotiations is indirect, i.e. through the Parties that in turn address these actors. However, the domestic actions of states are crucial in creating and maintaining the conditions that spurn and attract climate-friendly investments and make finance flows, both domestic and international, go towards low greenhouse gas emissions and climate-resilient development. ${ }^{36}$ A home for Article 2(1)(c) in the climate regime could be an opportunity and encouragement for Parties to define and showcase their efforts. However, as mentioned above, Article 2(1)(c) does not mean that the same domestic actions are suitable for all Parties.

Although the climate negotiations are only a small part of the big picture of financial flows, addressing Article 2(1)(c) has the potential to send a signal to relevant actors, including the private sector, to re-assess and redirect investments. Such policy 'signals' from the climate regime may be weak in legal and normative terms, but they can well influence investment strategies and have significant real-world impacts. A home for addressing Article 2(1)(c) in the climate negotiations could also be an opportunity to bring the views and expertise of other relevant actors into the

\footnotetext{
36 These have also been discussed under the label of 'enabling environments'; see Gastelumendi and Gnittke (n 2) 250.

37 Paris Agreement (n 4) arts 9, 10, 11, 13(9) and 13(10).

38 ibid art 13(3).

39 Paris Agreement (n 4) art 13(1). See also Christopher CampbellDuruflé, 'Rain or Sunshine in Katowice? Transparency in the Paris Agreement Rulebook' (2018) 12 CCLR.

40 Bodle and Oberthür (n 5) 103.

41 Paris Agreement (n 4) art 13(6)
}

climate regime - an approach that has increasingly been used in the climate regime and under the Paris Agreement.

\section{Transparency of Support: Old and Over-Discussed}

\section{Context}

Transparency of support relates to the delivery of information and data on support within the UNFCCC. To fully understand the importance of transparency of support in the implementation of the Paris Agreement it is important to first have a clear understanding of the different layers of this concept and how these are being tackled in the current negotiations.

The term 'support' as used in the climate regime does not only include financial support, but also technology development and transfer, and capacitybuilding support to developing country Parties. ${ }^{37} \mathrm{Al}-$ though the focus within the current negotiations is mainly on transparency of financial support, a full consideration of all three forms of support and their close interconnection is required to strengthen transparency of support under the Paris Agreement.

There already is an extensive set of transparency obligations and guidelines under the UNFCCC. The Paris Agreement requires Parties to 'build on and enhance' the existing transparency arrangements. ${ }^{38}$ The overall purpose of the enhanced transparency framework for action and support is to build mutual trust and confidence and to promote effective implementation. ${ }^{39}$ While the provisions on transparency are obligations in their own right, they also add teeth to the prescriptiveness of the overall regime. ${ }^{40}$ The purpose specifically of transparency of support is to provide clarity on support provided and received by relevant individual Parties in the context of climate change actions and to provide, to the extent possible, a full overview of aggregate financial support provided, to inform the global stocktake. ${ }^{41}$ In the current negotiations, the focus is on the development of the modalities, procedures and guidelines of these reports, as they are the basis of information for clarity, trust and effective implementation. Further time and efforts are however required to ensure that the framework goes beyond these reports, into an aggregate overview, analyses of other sources of data, reviews, consideration of progress and the delivery of sources 
of input to the global stocktake, in order to fully fulfil its purpose.

In contrast to transparency of action, different Parties have different reporting requirements on transparency of support. Developed country Parties shall, and other Parties that provide support should, provide information on support provided to developing country Parties, ${ }^{42}$ while developing country Parties should provide information on support needed and received. ${ }^{43}$ COP 24 is expected to adopt common modalities, procedures and guidelines, building on experience from the transparency arrangements under the Convention and taking into account Parties different capacities. ${ }^{44}$ Under Article 9(7), it is further stipulated that developed country Parties shall provide information on support for developing country Parties provided and mobilised through public interventions in accordance with these modalities, procedures and guidelines, while other Parties are encouraged to do so. ${ }^{45}$

These provisions explain why the current focus in the negotiations is on the modalities of financial support provided and mobilised through public interventions by developed country Parties: The experience to build on is more substantial with guidelines and common tabular formats, these countries have more capacities and there is a specific agenda item under the PAWP. That said, support needed and received by developing country Parties is also an important cornerstone of the enhanced transparency framework.

The information on support provided shall undergo a technical expert review and each Party shall participate in a facilitative, multilateral consideration of progress (FMCP) with respects to efforts on financial support. ${ }^{46}$ While the review will mainly assess if the information provided by countries is in line with the modalities, procedures and guidelines, and perhaps identify areas for improvement, the role of the FMCP regarding transparency of support is hardly being discussed in the current negotiations.

Besides these direct references related to transparency of support within the Paris Agreement, there are other provisions relevant to ensure an 'enhanced' transparency framework under the Paris Agreement. These linkages are identified in the informal note capturing the draft elements for modalities, procedures and guidelines for the transparency framework for action and support referred to in Article 13 of the Paris Agreement. ${ }^{47}$ There are provisions that could be linked to transparency of support within the tech- nology framework, the adaptation communication, the global stocktake, the committee to facilitate implementation and promote compliance, and information to be provided by Parties in accordance with Article 9(5) of the Paris Agreement. ${ }^{48}$ However, there is no consensus among Parties if all and to what extent these provisions are linked to transparency of support.

\section{Importance}

The purpose of transparency of support is to provide clarity on support, enhance trust and confidence, and to promote implementation. In this section we identify steps on how the current negotiations predominantly on modalities can ensure that the enhanced transparency framework delivers on its purpose.

Getting clarity on support requires, first of all, identification of why the information is being collected, as this influences how the information is collected. The Paris Agreement provides a general description relating it to support provided and received in the context of climate change actions under Articles 4, 7, 9, 10 and $11 .{ }^{49}$ Considering Article 9, developed country Parties shall provide financial resources to assist developing country Parties with respect to both mitigation and adaptation in continuation of their existing obligations under the Convention; ${ }^{50}$ and, as part of a global effort, should continue to take the lead in mobilising climate finance from a wide variety of sources, instruments and channels, through a variety of actions, and taking into account the needs and priorities of developing country Parties. ${ }^{51}$ Deci-

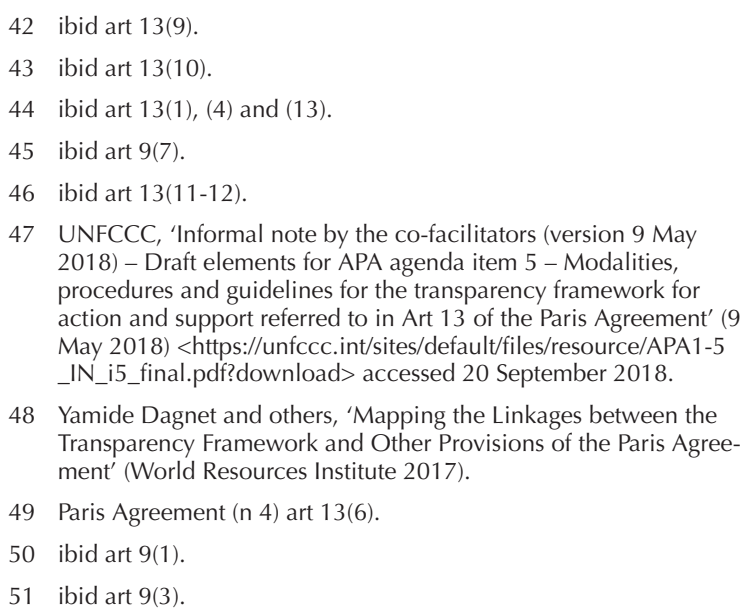

48 Yamide Dagnet and others, 'Mapping the Linkages between the Transparency Framework and Other Provisions of the Paris Agreement' (World Resources Institute 2017).

49 Paris Agreement (n 4) art 13(6).

50 ibid art 9(1).

51 ibid art 9(3). 
sion 1/CP.21 further stipulates that, in accordance with Article 9(3), developed countries intend to continue their existing collective mobilisation goal through 2025 in the context of meaningful mitigation actions and transparency on implementation and that prior to 2025 the CMA shall set a new collective quantified goal from a floor of USD 100 billion per year, taking into account the needs and priorities of developing countries. ${ }^{52}$

Therefore, a first step towards clarity on support is to ensure that the information collected provides the data that is necessary to follow-up up on these provisions in a transparent manner. It is clear that the reports of the individual Parties alone only provide a partial response to these provisions. The complexity of the climate finance landscape requires further analyses and the inclusion of other sources of data. These could be captured in the full overview of aggregate financial support provided, preferably as part of the Standing Committee on Finance's biennial assessment and overview of climate financial flows to avoid duplication of reports. The second step is, therefore, to allow for analysing the data as it is relevant for different purposes.

The trust-building exercise might be more difficult to achieve as Parties have different views on the goals set in the Paris Agreement. It is therefore difficult to expect that the transparency framework will deliver the information according to the different interpretations in a clear-cut manner. It is challenging to attain trust through transparency of support if there is no common view on the objectives to begin

52 Decision 1/CP.21 (n 5) para 53

53 Romain Weikmans J Timmons Roberts, 'The International Climate Finance Accounting Muddle: Is There Hope on the Horizon?' $(2017$ fc) Climate and Development.

54 UNFCCC 'Decision 1/CP.15, Outcome of the Work of the Ad Hoc Working Group on Long-term Cooperative Action under the Convention' UN Doc FCCC/CP/2009/11/Add.1 (30 March 2010).

55 UNFCCC 'Decision 1/CP.16, The Cancun Agreements: Outcome of the Work of the Ad Hoc Working Group on Long-term Cooperative Action under the Convention' UN Doc FCCC/CP/2010/7/Add.1 (15 March 2011).

56 UNFCCC 'Decision 2/CP.17, Outcome of the Work of the Ad Hoc Working Group on Long-term Cooperative Action under the Convention' UN Doc FCCC/CP/2011/9/Add.1 (15 March 2012)

57 UNFCCC 'Decision 19/CP.18, Common Tabular Format for "UNFCCC Biennial Reporting Guidelines for Developed Country Parties"' UN Doc FCCC/CP/2012/8/Add.3 (28 February 2013); UNFCCC 'Decision 9/CP.21, Methodologies for the Reporting of Financial Information by Parties Included in Annex I to the Convention' UN Doc FCCC/CP/2015/10/Add.2 (29 January 2016). with. This can be illustrated by the collective commitment goal of developed countries to jointly mobilise USD 100 billion by 2020 , in the context of meaningful mitigation and transparency of implementation. The Organisation for Economic Cooperation and Development (OECD) and Climate Policy Initiative report and the subsequent response by the Indian Ministry of Finance on this report gives a good example of the range of interpretations of what counts towards the goal: USD 57 billion versus USD 2.2 billion on average for 2013-2014. ${ }^{53}$ The divergent views on this goal and other elements, such as a definition on climate finance, might be too strong to overcome and negotiations should focus on different, more innovative ways to enhance trust. One way could be to define the data to be provided sufficiently broadly to accommodate all views.

Last but not least, transparency of support should promote implementation. In addition to clarity on support and trust, this should also be embedded in the development of the relevant modalities. These modalities should provide the basis of information to have knowledge about support and how it is being delivered and used. How effective is the support provided and mobilised? What is the impact of the support received? If the transparency framework is able to respond to these questions, the use and usefulness of the framework will be very significantly enhanced compared to the current system, which makes such assessments difficult.

\section{Is It Over-Discussed?}

There are several reasons why transparency of support can be considered as being over-discussed within the UNFCCC negotiations. First for historical reasons, as the development of guidelines, modalities and reporting formats has been a long-standing issue on the UNFCCC agenda since COP 16 in Cancún (2010). On the basis of the Copenhagen Accord ${ }^{54}$ and the Cancun Agreements ${ }^{55}$, COP 17 (Durban) agreed on the guidelines for the current Biennial Reports (developed countries) and Biennial Update Reports (developing countries). ${ }^{56}$ The following year, the common tabular format for reporting by developed countries was approved, which was improved at COP 21 in Paris with regard to methodologies for the reporting of financial information by Parties included in Annex I to the Convention. ${ }^{57}$ 
Second, the Paris Agreement Work Programme, as mentioned above, includes several agenda items related to transparency of support. The discussion mainly takes place under the APA agenda item on the development of the modalities, procedures and guidelines of the enhanced transparency framework referred to in Article 13 of the Paris Agreement and under the agenda item of the Subsidiary Body on Scientific and Technological Advice (SBSTA) on modalities for the accounting of financial resources provided and mobilised through public interventions, in accordance with Article 9(7) of the Paris Agreement. To come to an efficient and coherent transparency framework, it is necessary to also consider the linkages, and to avoid the risk of developing reporting requirements which are not in line with the modalities under the transparency framework. ${ }^{58}$

A third reason is the technical complexity of transparency of support due to the wide variety of types, sources and channels of support as well as methodological and definitional challenges of reporting this support. This complexity has led to research by other institutions, such as the OECD and efforts by other players to overcome some of the challenges, such as the Common Principles for Tracking Climate Finance by the multilateral development finance institutions. ${ }^{59}$ The development of modalities should understand and acknowledge the complexity by building on the expertise from outside the UNFCCC to capture the most recent developments since the agreement on the guidelines for the biennial reports for developed countries and biennial update reports for developing countries. ${ }^{60}$

Finally, the political importance of the issue has increased over the years. Although this has not per se led to a further increase of discussion time, it has led to more intensity within the current negotiations. The abovementioned OECD and Climate Policy Initiative report, ${ }^{61}$ commissioned by the Peruvian and French COP Presidencies, can be identified as one of the turning points in these discussions as it exposed the divergent views by countries on what counts towards the USD 100 billion goal and showed the importance of having clarity on the methodologies beyond the number(s). ${ }^{62}$

While this shows that transparency of support is an important, long-standing issue in the UNFCCC negotiations, it also shows that there is an imbalanced approach towards its different layers. The focus is almost solely on the financial support provided by de- veloped countries, with less time dedicated towards the overall picture, the linkages with other items and bodies under and outside the Convention, support needed and received by developing countries and the two other forms of support, technology development and transfer and capacity-building.

\section{Challenges and Implications}

Political challenges relate first of all to the lack of an agreed understanding on definitions and crucial concepts, such as climate finance and what counts towards the USD 100 billion goal. But political challenges also relate to the pursuit of a balanced progress between the different elements of the PAWP. In relation to transparency of support, there is already an imbalance due to the strong emphasis on support provided by developed country Parties, but it goes further as many Parties keep a close eye on a balanced outcome between transparency of action and of support. If this led Parties to make progress on both aspects of the transparency framework, it could achieve a sum bigger than its parts. If not, there is a risk of agreeing on the lowest common denominator. An open dialogue and exchange of views and information to take account of progress across different tracks is key to the overall success of the negotiations, even if progress is uneven. ${ }^{63}$

Technical challenges relate to the current methodological shortcomings, which require room for error and further improvements. The methodologies are still evolving, especially on support needed and received and mobilised by public interventions. Capturing the progress made since the adoption of the current biennial report and biennial update report guidelines at COP 17 would already be a major step forward in the transparency framework under the Paris Agreement. On the other hand, it also entails a

\footnotetext{
58 Dagnet and others (n 45).

59 The World Bank, 'Developing Common Principles for Tracking Climate Finance' <http://www.worldbank.org/en/news/feature/ 2015/04/03/common-principles-for-tracking-climate-finance> accessed 20 September 2018

60 Decision 2/CP.17 (n 57).

61 OECD, 'Climate Finance in 2013-14 and the USD 100 Billion Goal: A Report by the OECD in Collaboration with Climate Policy Initiative' (OECD Publishing 2015).

62 Weikmans and Roberts (n 50).

63 Dagnet and others ( $\mathrm{n} 45$ )
} 
risk if it locks in certain methodologies that are currently being used as the best alternative to nothing, but have little added value in the longer run, such as the use of the OECD's 'Rio Markers' to quantify financial information and the reporting on core/general contributions to capture contributions through multilateral channels.

\section{Real-World Impacts}

If full consideration is given to the different layers of transparency of support, including its interlinkages with other items, if the modalities on transparency of support are balanced between the different forms of support, if the provisions on transparency of support are developed in a way that ensures its purpose, and if the challenges are overcome in an innovative manner, then the real-world impact of the transparency framework could be considerable. It would allow for the identification of trends on climate support, a sense of where we stand in supporting climate action of developing countries and in mobilizing climate finance, if we are on a pathway towards the quantitative goals by 2020 and by 2025 , and how to provide support more effectively to raise ambition.

\section{Conclusions}

Both of the particular finance issues addressed in this contribution, Article 2(1)(c) and transparency of sup- port, have a double function: Article 2(1)(c) is a goal of the Paris Agreement in its own right, while at the same time it is an essential means to achieve the other two mitigation and adaptation goals. The provisions on transparency and accountability have a double function as obligations in their own right, as well as supporting the prescriptiveness of the overall regime.

In view of the ongoing negotiations, conclusions regarding $\mathrm{COP} 24$ are tentative: Article 2(1)(c) can be regarded as under-discussed, because despite its overarching importance it currently has no adequate home in the climate negotiations for Parties to discuss and address it holistically. It would be a missed opportunity if a home for further work on Article 2(1)(c) was not found at COP 24. A new agenda item seems unlikely. One option is a dedicated work stream under the global stocktake, provided it has an adequate mandate. Article 2(1)(c) could also be included in existing agenda items and mandates such as the current COP agenda item on 'long-term finance'. In a similar vein, Article 2(1)(c) could be included if Parties were to discuss this bigger picture of climate finance under the Paris Agreement in the future.

With regard to transparency of support, a potential way forward to COP 24 would be to finalise the modalities of the transparency framework. Moreover, a master plan on transparency of support should be agreed to identify further steps after COP 24 by capturing progress made so far at COP 24 and CMA 1 , as well as a work plan for the remaining issues. 